\title{
Dynamic and Volatility of World Agricultural Market Prices: Impacts on Importations and Food Security in WAEMU
}

\author{
Baoubadi Atozou ${ }^{1,2,3} \&$ Koffi Akakpo ${ }^{2,4}$ \\ ${ }^{1}$ Department of Agri-food Economics and Consumers Science, Laval University, Canada \\ ${ }^{2}$ Center for Research in Economics of Environment, Agri-Food, Transport and Energy (CREATE), Laval \\ University, Canada \\ ${ }^{3}$ Egg Industry Economic Research Chair, Laval University, Quebec, Canada \\ ${ }^{4}$ Department of Economic, Laval University, Canada \\ Correspondence: Baoubadi Atozou, Department of Agri-food Economics and Consumer Science, Laval \\ University, Quebec City, Quebec, G1V0A6, Quebec, Canada, Tel: 1-581-777-4874. E-mail: \\ baoubadi.atozou.1@ulaval.ca
}

Received: September 18, 2017

Accepted: November 2, $2017 \quad$ Online Published: November 20, 2017

doi:10.5539/ijef.v9n12p180

URL: https://doi.org/10.5539/ijef.v9n12p180

\begin{abstract}
Over the last decade, the use of foodstuffs such as corn, wheat and soybean in biofuels production has been growing sharply in the United States, Canada and Europe. This growth has increased total demand for agricultural commodities and stimulated agricultural prices. However, corn, rice, wheat and soybean are the most important sources of calorific energy for West African Economic and Monetary Union (WAEMU) member states' population, and WAEMU countries are highly dependent on the imports of these products. Consequently, rising prices can have an important impact on imports and severe consequences on food security in these developing countries. This paper aims to investigate: (i) the short-term and long-term relationships between the prices of corn, rice, wheat, soybean and oil and their volatilities, and (ii) the effects of these agricultural commodities prices shocks on the imports of each WAEMU member states. The Autoregressive Distributed Lag (ARDL) model, the Multivariate Generalized Autoregressive Conditional Heteroskedasticity (MGARCH) model and the Granger causality test are used in this investigation. The results show that imports of agricultural commodities in WAEMU countries are highly and significantly sensitive to price changes in international market. In short term as well as in long term, there is a significant relationship between the prices of these products. We find a positive relationship in general between prices volatilities, and negative effects of price volatility on imports. Thus, distortions in world agricultural markets threaten considerably food security in WAEMU countries, especially access to food for vulnerable and low-income populations. Policy makers must adopt viable strategies to increase agricultural production and limit their dependence on imports.
\end{abstract}

Keywords: price volatility, import of agricultural commodities, food security, WAEMU, distortions of world agricultural market

\section{Introduction}

In the 2000s decade, the global economy has witnessed a steady increase in energy prices, caused by the low sensitivity of global demand relative to cyclical changes in world oil prices (Stuber, 2001). Oil importing countries then saw their oil bills gradually reach record levels. This is inevitably a major problem for countries that are more likely to use petroleum products such as the United States. Several renewable energy laws were passed during this decade to reduce their energy dependence. Indeed, the Energy Policy Act 2005, the Energy Independence and Security Act 2007, and the 2008 Farm Bill were adopted by the US Congress to encourage the development and growth of alternative energy production to petroleum fuels (Yacobucci, 2010).

Ethanol and biodiesel, the two most widely used biofuels, have received considerable support from the federal government who provides incentives for increased production, such as: tax incentives, loan and subsidy programs and regulatory requirements (Yacobucci, 2010; Sissine 2007). According to these authors, fuel suppliers are required to use nine billion gallons in 2009 and up to 36 billion gallons in 2022. US ethanol production has grown from $42 \%$ of world production in 2007 to $48 \%$ in 2011 (Hahn, 2012). 
Sugar cane (Brazil) and sugar beet (Europe) are the most efficient inputs in the production of ethanol. On the other hand, in North America and particularly in the United States, ethanol production is made from cereals or starch-rich plants such as grain corn and wheat (CRAAQ, 2008). In 2008, 142 plants had a production capacity of more than 30.5 billion liters of ethanol per year in the United States, or 6\% of the total domestic demand for gasoline (CRAAQ, 2008) made from corn. In addition, wheat, rice and maize are the most consumed cereals in the world. The United States is the largest maize producer in the world. They have covered an average of $40 \%$ of global demand over the last five years. They are also the largest maize exporter, an average of $56 \%$ of global demand has been covered in the period 2006-2011 (O'Brien, 2011). Thus, global cereal production is divided between: feeding the world's population and producing biofuel.

Moreover, over the period 2007-2008, agricultural markets were marked by a sharp rise in the prices of agricultural commodities on the world market, leading to a global food crisis. Prices for staples such as wheat, soybean and rice have surged by more than $40 \%$ since the beginning of 2007 and over $60 \%$ for rice (UNCTAD, 2008; CNUCED, 2008). Household food expenditures have exploded, aggravating the situation of the low-income households, especially in developing countries. This crisis comes at a time when the United States has intensified its production of biofuels, the main input of which is maize, through the adoption of several laws in the 2000s decade on independence and energy security aimed at the development of biofuels. This raises the question of the impact of these biofuel production policies, in particular ethanol, on the 2007-2008 food crisis. Several authors believe that the Ethanol Act did not have a significant impact on the global cereal market to exacerbate this crisis. They have attributed the factors driving this crisis mainly to the imbalances between supply and demand, the low level of stocks, the speculative behavior of certain economic agents on the agricultural stock markets, the fall in exports of agricultural products, the depreciation of the US dollar, the rising energy prices and the financial crisis of the period (UNCTAD, 2008; Maetz, 2012).

Meanwhile, rice, maize and wheat are the most widely consumed food commodities in WAEMU countries. According to the report on food consumption in West Africa, the calorific contribution of rice to food consumption was $30 \%$ on average in Senegal, $19 \%$ in Côte d'Ivoire, $10 \%$ in Togo, $8 \%$ in Burkina Faso over the period 2004-2008 (Taondyandé \& Yade, 2011). Maize is the most consumed cereal with an energy contribution of 24\% in Togo, 12\% in Burkina Faso, 11\% in Senegal and 6.4\% in Côte d'Ivoire over the same period. Wheat is a commodity imported into the area and consumed in Senegal, Côte d'Ivoire and Togo. In WAEMU countries, people depend heavily on agri-food markets - In Togo, households buy $80 \%$ of their food needs, almost $86 \%$ in Senegal, almost $81 \%$ in Mali, $76 \%$ in Côte d'Ivoire, 62\% in Burkina Faso (Taondyandé \& Yade, 2011). Households put up to $50 \%$ of their total expenditure on food consumption (Taondyande \& Yade, 2011). This shows that the volatility and rise in world food prices strongly affect the level of food security in this part of the world and consequently deteriorate household living conditions. In the last decade, agricultural markets have been very volatile. Moreover, the outcome of the US presidential elections has increased uncertainty in these markets. Revisiting the analysis of the dynamics of the world prices of agricultural products, their volatility and their impact on imports of agri-food products in the different countries of the WAEMU zone is therefore necessary to guide decision-makers.

The purpose of this paper is to analyze (i) the short-term and long-term relationships between world commodities prices (rice, wheat, maize and oil); (ii) the transmission of price shocks or volatility between prices of rice, maize, wheat and oil; (iii) the effects of price shocks and volatilities on the level of imports of agricultural products in the different WAEMU countries.

The rest of the paper is organised as follows. Section 2 presents the econometric methods used in this investigation and sets out the data. Section 3 highlights the different empirical results obtained and Section 4 provides a critical analysis of a food security policy. Finally, Section 5 concludes and gives recommendations.

\section{Materials and Econometric Models}

\subsection{Econometrics Models}

The analysis of agri-food price dynamics is generally based on the classic econometric models of time series such as autoregressive vector (VAR), Structural VAR (SVAR), and error correction model (Wang, 2014; Sadrosky, 2014; Mensi et al., 2014; Jababli et al., 2014; Gross, 2017). In the last decade, new models of analysis of short and long-term relationships, and asymmetric price transmission tests between producers, processors and retailers such as Autoregressive Threshold (TAR) and Momentum Models Autoregressive Threshold (MTAR) were developed and applied (Enders \& Siklos, 2001; Olemu \& Ogundeji, 2010; Sun 2011; Surathkal et al., 2014, Ning \& Sun, 2014; Alam \& Jha, 2016; Ankamah-Yeboah \& Bronnmam, 2017). The necessary hypothesis that validates the application of the three models (MEC, TAR and MTAR) for the simultaneous analysis of short and 
long-term relationships between economic indicators is that all variables included in the model must be integrated in the same order d (I (d)) (Enders \& Siklos, 2001). In addition, Pesaran, Shin and Smith (2001) developed a new approach to more effectively test the existence of a relationship between a dependent variable and a set of supposedly exogenous variables when it is not known with certainty whether the exogenous variables considered are stationary in trend or difference. This model, called Autoregressive Distributed Lag Model (ARDL), was developed in 2001 by Pesaran, Shin and Smith. The ARDL approach of long-term relation to level implies a conditional estimation of the version of the error correction of ARDL model expressing the dependent variables as a function of the exogenous variables. In this paper, we first investigate the long-term relationship between world commodities prices (rice, wheat, maize, soybean and oil). The price variables of agricultural products are considered dependent and the price of oil is considered exogenous. Thus, for each agricultural product we estimate an ARDL model conditional on the prices of other agricultural products and the price of oil. We therefore have four types of equation expressed in the following form:

$$
\begin{aligned}
& \Delta \ln P_{t}^{r}=\delta_{0}+\sum_{i=1}^{P} \delta_{i}^{r} \ln \Delta P_{t-i}^{r}+\sum_{i=1}^{P} \delta_{i}^{m} \ln \Delta P_{t-i}^{m}+\sum_{i=1}^{P} \delta_{i}^{w} \ln \Delta P_{t-i}^{w}+\sum_{i=1}^{P} \delta_{i}^{s} \ln \Delta P_{t-i}^{s}+\sum_{i=1}^{P} \delta_{i}^{p} \Delta \ln P_{t-i}^{p}+ \\
& \pi_{1} \ln \Delta P_{t-1}^{r}+\pi_{2} \ln \Delta P_{t-1}^{m}+\pi_{3} \ln \Delta P_{t-1}^{w}+\pi_{4} \ln \Delta P_{t-1}^{s}+\pi_{5} \ln \Delta P_{t-1}^{p}+\varepsilon_{t} \\
& \Delta \ln P_{t}^{m}=\beta_{0}+\sum_{i=1}^{K} \beta_{i}^{m} \ln \Delta P_{t-i}^{m}+\sum_{i=1}^{K} \beta_{i}^{w} \ln \Delta P_{t-i}^{w}+\sum_{i=1}^{K} \beta_{i}^{r} \ln \Delta P_{t-i}^{r}+\sum_{i=1}^{K} \beta_{i}^{s} \ln \Delta P_{t-i}^{s}+\sum_{i=1}^{K} \beta_{i}^{p} \Delta \ln P_{t-i}^{p}+ \\
& \gamma_{1} \ln \Delta P_{t-1}^{r}+\gamma_{2} \ln \Delta P_{t-1}^{m}+\gamma_{3} \ln \Delta P_{t-1}^{w}+\gamma_{4} \ln \Delta P_{t-1}^{s}+\gamma_{5} \ln \Delta P_{t-1}^{p}+u_{t} \\
& \Delta \ln P_{t}^{s}=\rho_{0}+\sum_{i=1}^{J} \rho_{i}^{S} \ln \Delta P_{t-i}^{s}+\sum_{i=1}^{J} \rho_{i}^{m} \ln \Delta P_{t-i}^{m}+\sum_{i=1}^{J} \rho_{i}^{w} \ln \Delta P_{t-i}^{w}+\sum_{i=1}^{J} \rho_{i}^{r} \ln \Delta P_{t-i}^{r}+\sum_{i=1}^{J} \rho_{i}^{p} \Delta \ln P_{t-i}^{p}+ \\
& \mu_{1} \ln \Delta P_{t-1}^{r}+\mu_{2} \ln \Delta P_{t-1}^{m}+\mu_{3} \ln \Delta P_{t-1}^{w}+\mu_{4} \ln \Delta P_{t-1}^{s}+\mu_{5} \ln \Delta P_{t-1}^{p}+v_{t} \\
& \Delta \ln P_{t}^{w}=\tau_{0}+\sum_{i=1}^{D} \tau_{i}^{s} \ln \Delta P_{t-i}^{s}+\sum_{i=1}^{D} \tau_{i}^{m} \ln \Delta P_{t-i}^{m}+\sum_{i=1}^{D} \tau_{i}^{w} \ln \Delta P_{t-i}^{w}+\sum_{i=1}^{D} \tau_{i}^{r} \ln \Delta P_{t-i}^{r}+\sum_{i=1}^{D} \tau_{i}^{p} \Delta \ln P_{t-i}^{p}+ \\
& \varphi_{1} \ln \Delta P_{t-1}^{r}+\varphi_{2} \ln \Delta P_{t-1}^{m}+\varphi_{3} \ln \Delta P_{t-1}^{w}+\varphi_{4} \ln \Delta P_{t-1}^{s}+\varphi_{5} \ln \Delta P_{t-1}^{p}+n_{t}
\end{aligned}
$$

With $P_{t}^{r}, P_{t}^{m}, P_{t}^{w}, P_{t}^{s}$, and $P_{t}^{p}$ representing respectively the prices of rice, maize, wheat, soybean and oil. All variables are transformed to their logarithmic form and are taken in the first difference $(\Delta)$. Equations 1, 2, 3 and 4 are called the error-correction version of the ARDL model because of the linearity of the long-term relationship represented by the coefficients $\pi_{k}, \gamma_{k}, \mu_{k}$, and $\tau_{k}$ (Baek \& Koo, 2009). According to Pesaran, Shin and Smith (2001), the ARDL model is a test approach for the relationship between a dependent variable and a set of independent variables. This test is based on the standard Fischer test used to test the significance of delay levels in a varied plain error correction mechanism (Pesaran et al., 2001). In contrast to the standard error-correction model which is based on the fact that endogenous variables are integrated in the same order, the ARDL model assumes that each variable is Stationary in level I(0) or in first difference I(1) (Engel \& Granger, 1987; Johannsen, 1995, Enders \& Siklos, 2001). It is thus a bounded cointegration test that provides two critical F-test values for each confidence level corresponding to the case where all the variables are purely $\mathrm{I}(0)$ and purely $\mathrm{I}(1)$. These two critical values define a band covering all the possibilities of classification of the variables going from purely $\mathrm{I}(0)$ to purely I(1) or mutually cointegrated (Pesaran et al., 2001). This ARDL approach is more robust and efficient with small samples than other cointegration techniques (Pesaran \& Shin, 1999; Pesaran et al., 2001, and Baek \& Koo, 2009).

The Multivariate Generalized Autoregressive Conditional Heteroskedasticity (MGARCH) model was used to analyze the transmission of shocks between agricultural products prices on the international market, specifically between the prices of rice, maize, wheat and soybean. This approach allows us to see how the dynamics of shocks on each agricultural product affects the dynamics of the prices of other commodities, and hence the level of food security in countries heavily dependent on imports.

The ARDL approach of long-term bounded test is also used to investigate the relationship between the levels of rice and wheat imports by Togo, Mali, Benin, Senegal, Côte d'Ivoire and Burkina Faso. The level of risk aversion of firms importing agricultural products can affect their level of imports. The higher the volatility of prices, the more risk-averse firms can reduce their level of import and consequently affect the availability of food in the local market. This can lead to food insecurity due to rising prices, to inadequate supply which result overall in an ever-increasing demand. According to economic theory, demand is a decreasing function of price. Indeed, the rise in prices can lead to a fall in imports of agricultural products and consequently to an increase prices on the local market. Per capita import and global import quantities were considered dependent variables and prices of rice and wheat and their volatilities as exogenous variables. Rice and wheat were selected because of the heavy import dependency of the West African countries mentioned above. The ARDL equations express the relationship between imports, price levels and their volatility are specified as follows:

$$
\begin{gathered}
\Delta \ln M_{t}^{r}=\varphi_{0}+\sum_{k=1}^{S} \psi_{k} \Delta \ln M_{t-k}^{r}+\sum_{k=1}^{S} \lambda_{k} \Delta \ln P_{t-k}^{r}+\sum_{k=1}^{S} \Omega_{k} \ln S D_{t-k}^{p^{r}}+\alpha_{1} \ln M_{t-1}^{r}+\alpha_{2} \ln P_{t-1}^{r}+\omega_{t} \\
\Delta \ln M_{t}^{w}=\xi_{0}+\sum_{k=1}^{S} \xi_{k} \Delta \ln M_{t-k}^{w}+\sum_{k=1}^{S} \zeta_{k} \Delta \ln P_{t-k}^{w}+\sum_{k=1}^{S} \eta_{k} \ln S D_{t-k}^{p^{w}}+\theta_{1} \ln M_{t-1}^{w}+\theta_{2} \ln P_{t-1}^{W}+z_{t}
\end{gathered}
$$


With $M_{t}^{r}$ and $M_{t}^{w}$ representing respectively the import level of rice and wheat at period $\mathrm{t}$, and $P_{t}^{r}$ and $P_{t}^{w}$ respectively the price on the international market for rice and wheat in period t. The error terms $\omega_{t}$ and $z_{t}$ respectively follow a white noise process. $S D_{t}^{p^{r}}$ and $S D_{t}^{p^{w}}$ represent respectively the standard deviation of the price of rice and wheat, calculated annually according to the monthly data of each year. They materialize the series of annual volatility of agricultural commodity prices. The following section presents the data used in the empirical estimation of the different econometric models.

\subsection{Data Description}

Monthly data on the prices of agricultural products (rice, maize, wheat, soybean and oil) are available on the United Nations Conference on Trade and Development (UNCTAD) website. These monthly data were used to analyze the synergies between the price dynamics of these main agri-food products. The analysis of price volatility using the multivariate GARCH model is based on these monthly data. Figure 1 shows the evolution of these prices over the period January 1999 to December 2016. The trends show graphically interdependent relationships between the prices of agricultural products on the world market. Indeed, Figure 1 shows, for example, that the evolution of maize price follows the dynamic of wheat price with a small lag. Among agricultural products, the price of maize is the most volatile with a coefficient of variation 8.34 against 7.51 for rice, 7.07 for wheat and 6.84 for soybean. However, the price of a barrel of oil remained more volatile (14.81) than the prices of agricultural commodities. Figure 4 (see Appendix A) presents the dynamics of annuals commodities prices and their imports levels for each WAEMU country.

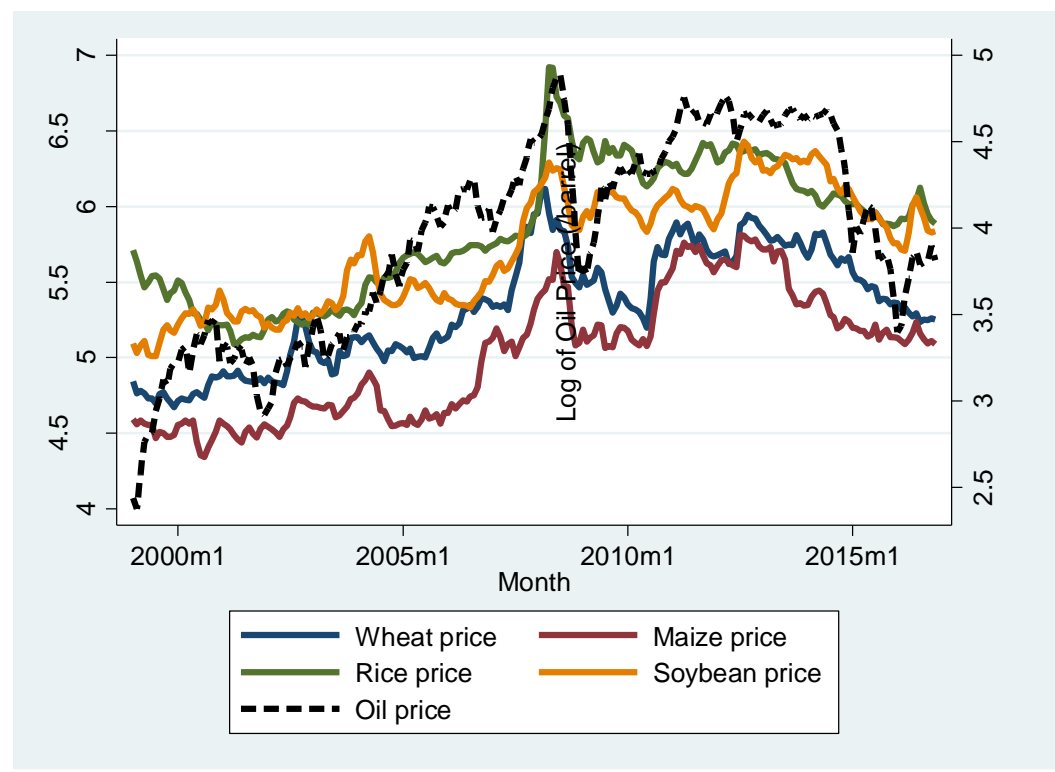

Figure 1. Dynamics of monthly world market prices of agricultural products prices in logarithm (price / tonne) and oil price (price / barrel) over the period 1999-2016

The monthly data were used to calculate the average annual prices of these agricultural products. Data on import levels of rice and wheat for each considered WAEMU country were obtained from the FAO website. The rice and wheat prices volatility series are obtained by calculating the standard deviation (SD) of the monthly price for each year $\mathrm{T}$.

$$
S D_{T}=\sqrt{\frac{1}{12} \sum_{k=1}^{12}\left(P_{T k}-\bar{P}_{T}\right)^{2}}
$$

With $P_{T k}$, the price of the agricultural commodity at month $k$ of year $T$ and $\bar{P}_{T}$ the monthly average price of year T. The figure in Appendix A represents the dynamics of the imports flows of rice and wheat for each country according to the price level of these products.

\section{Empirical Results and Discussions}

\subsection{Unit Root and Granger Causality Tests}

The Augmented Dickey-Fuller and Phillips Perron tests are used to investigate the presence of unit root in the 
price and import variables. This stationarity test is a necessary condition in the ARDL model approach. The condition is that all variables of the model must be $\mathrm{I}(0)$ or $\mathrm{I}(1)$. The results of the stationarity tests suggest that all the series are I(1) which fulfills this condition. The cointegration relationship tests according to the ARDL approach provide two values, one in case all the variables of the model are I( 0$)$ and the other in case all the variables are I(1). The Fischer test is used to analyze the existence of the long-term relationship between the variables of the model. If the empirical statistic of the Fischer test is greater than the critical value of the upper bound I(1) defined by Pesaran, Shin and Smith (2011), then there is a statistically significant cointegration relationship. If the empirical F-statistic is between the lower bound $\mathrm{I}(0)$ and the upper bound $\mathrm{I}(1)$ then, according to Pesaran, Shin and Smith (2001), one cannot conclude on the existence of the long-term relationship between the variables. If, on the other hand, the empirical F-statistic is less than the critical value corresponding to I $(0)$ according to the table of Pesaran, Shin and Smith (2001) then there is no cointegration relation between the variables considered. Tables 1, 2 and 3 present the results of stationarity and Granger causality tests as well as the results of cointegration relation tests, estimates of long-run equations between prices of agricultural products and short-term relationships between these variables.

Table 1. Augmented Dickey Fuller and Phillips-Perron unit root test

\begin{tabular}{|c|c|c|c|c|c|c|}
\hline \multirow[b]{3}{*}{ Variable } & ADF-test & Phillipe-Perron & Decision & ADF test & Phillipe-Perron & Decision \\
\hline & \multicolumn{3}{|c|}{ In level } & \multicolumn{3}{|c|}{ First difference } \\
\hline & T-Stat. & T-Stat. & & T-Stat. & T-Stat. & \\
\hline Ln Wheat price & -1.79 & -1.66 & Unit root & $-7.89 * * *$ & $-11.40 * * *$ & Stationary \\
\hline Ln Maize price & -1.53 & -1.41 & Unit root & $-7.24 * * *$ & $-11.83 * * *$ & Stationary \\
\hline Ln Rice price & -1.30 & -1.28 & Unit root & $-6.70 * * *$ & $-8.53^{* * *}$ & Stationary \\
\hline Ln Soybean price & -1.86 & -1.77 & Unit root & $-7.20 * * *$ & $-9.37 * * *$ & Stationary \\
\hline Ln Oil price & -2.39 & -2.60 & Unit root & $-7.55^{* * *}$ & $-10.84 * * *$ & Stationary \\
\hline $5 \%$ Crit.value & \multicolumn{2}{|c|}{-2.882} & & \multicolumn{2}{|c|}{-2.882} & \\
\hline
\end{tabular}

Note. $* * * * *$ and $*$ denote Significance the $1 \%, 5 \%$, and $10 \%$ level respectively.

Table 2. Granger causality test between world agriculture commodities price

\begin{tabular}{lllc}
\hline Variable & Null Hypothesis & Variable & Chi2 (2) statistic \\
\hline Ln Wheat price & Does not Granger cause & Ln Maize price & 0.41 \\
Ln Wheat price & Does not Granger cause & Ln Rice price & $5.50^{*}$ \\
Ln Wheat price & Does not Granger cause & Ln Soybean price & 2.52 \\
Ln Wheat price & Does not Granger cause & Ln Oil price & 0.27 \\
Ln Maize price & Does not Granger cause & Ln Wheat price & $6.11^{* *}$ \\
Ln Maize price & Does not Granger cause & Ln Rice price & $14.66^{* * *}$ \\
Ln Maize price & Does not Granger cause & Ln Soybean price & $5.56^{*}$ \\
Ln Maize price & Does not Granger cause & Ln Oil price & 2.96 \\
Ln Rice price & Does not Granger cause & Ln Wheat price & $5.80^{* *}$ \\
Ln Rice price & Does not Granger cause & Ln Maize price & 1.51 \\
Ln Rice price & Does not Granger cause & Ln Soybean price & 0.36 \\
Ln Rice price & Does not Granger cause & Ln Oil price & 2.05 \\
Ln Soybean price & Does not Granger cause & Ln Wheat price & 2.44 \\
Ln Soybean price & Does not Granger cause & Ln Maize price & $7.58^{* *}$ \\
Ln Soybean price & Does not Granger cause & Ln Rice price & 1.63 \\
Ln Soybean price & Does not Granger cause & Ln Oil price & 0.14 \\
Ln Oil price & Does not Granger cause & Ln Wheat price & 0.59 \\
Ln Oil price & Does not Granger cause & Ln Maize price & 0.72 \\
Ln Oil price & Does not Granger cause & Ln Rice price & 4.06 \\
Ln Oil price & Does not Granger cause & Ln Soybean price & 1.83 \\
\hline
\end{tabular}

Note. $* * *, * *$ and $*$ denote Significance the $1 \%, 5 \%$, and $10 \%$ level respectively.

The Augmented Dickey Fuller (ADF) and Phillipe Perron tests (Table 1) show that all variables contain a unit root in level, but become stationary at the first difference. Table 2 presents the results of short-term causal interrelationship between rice, maize, wheat and soybean and oil prices. The Granger causality test is the tool used in causality analysis. The results (Table 2) show that the price of maize Granger cause respectively the rice 
price, wheat price and soybean price. There is also a two-way relationship between the price of rice and the price of wheat. In fact, the results show that the price of rice causes Granger's price of wheat and the price of wheat in Granger's sense causes the rice price at the $10 \%$ significant level. This sense of bidirectional causality is significant between maize and soybean prices. This latter result can be explained by the fact that maize and soybean are the main inputs in the livestock sector as livestock and poultry feed in developed countries and are widely used in the case of poultry in developing countries. Because rice, maize and wheat are substitute products and the main food commodities, prices are interconnected in the short term. For example, in Senegal, rice and wheat constitute the first foodstuffs. The main calorific energy sources are derived from these two agricultural products. However, the country heavily relies on imports of these commodities.

\subsection{Results of the Analysis of the Short and Long Term Relationships and the Volatility of Agricultural Prices}

The results of the rice, maize, soybean and wheat cointegration test with the ARDL model (see tables 3 and 4) show two statistically significant cointegration relationships at the 5\% level with as dependent variables wheat and rice. In other case, any cointegration relationship is inconclusive or significant. The estimated of short term and long-term parameters are respectively summarized in Table 3 and 4.

Table 3. Empirical results of estimates of our ARDL models (Cointegration test, Long-term and short-term relationships)

\begin{tabular}{|c|c|c|c|c|c|c|}
\hline \multicolumn{7}{|c|}{ ARDL cointegration test } \\
\hline & \multicolumn{2}{|c|}{ Ln Wheat price } & Ln Maize price & Ln Rice price & \multicolumn{2}{|c|}{ Ln soybean price } \\
\hline F-statistic & \multicolumn{2}{|c|}{5.730} & 1.717 & 4.471 & \multicolumn{2}{|c|}{2.830} \\
\hline Decision & \multicolumn{2}{|c|}{ Cointegrated } & Inconclusive & cointegrated & \multicolumn{2}{|c|}{ Cointegrated } \\
\hline \multicolumn{7}{|c|}{ Long-term coefficients estimations results } \\
\hline Variable & \multicolumn{2}{|c|}{ Ln wheat price } & Ln maize price & Ln rice price & \multicolumn{2}{|c|}{ Ln soybean price } \\
\hline Ln Wheat price & \multicolumn{2}{|c|}{-} & $0.629 * * *(0,068)$ & $-0.250 * *(0.114)$ & $0.307 * * *$ & $(0.087)$ \\
\hline Ln Maize price & $0.472 * * *$ & $(0.051)$ & - & $0.408^{* * *}(0.096)$ & $0.361 * * *$ & $(0.073)$ \\
\hline Ln Rice price & $-0.094^{* *}$ & $(0.043)$ & $0.204 * * *(0.048)$ & - & $0.262 * * *$ & $(0.052)$ \\
\hline Ln soybean price & $0.191 * * *$ & $(0.054)$ & $0.299 * * *(0.061)$ & $0.434 * * *(0.086)$ & \multicolumn{2}{|c|}{ - } \\
\hline Ln oil price & $0.247 * * *$ & $(0.031)$ & $(0.351)$ & $0.348 * * *(0.052)$ & -0.036 & $(0.045)$ \\
\hline Constant & 1.436 **** & $(0.145)$ & $-1.097 * * *(0.190)$ & $1.236 * * *(0.277)$ & $0.891 * * *$ & $(0.216)$ \\
\hline
\end{tabular}

Note. $* * * * *$ and $*$ denote Significance the $1 \%, 5 \%$, and $10 \%$ level respectively. Pr (Rice price), Pm (Corn price), Ps (Soybean price) et pw (Wheat price) et poil (Oil price). Standard Error is in the parentheses (.). According to the table of values of Pesaran, Shin and Smith (2001) the critical values of the Fischer test of the cointegration relations are: the criterion LR is the criterion of choice of the delay ( $\mathrm{k}=4$ ). $\mathrm{IC} \alpha=[\mathrm{I}(0), \mathrm{I}(1)] . \mathrm{IC}_{1 \%}=[3.74,5.06] \mathrm{IC}_{5 \%}=[2.86,4.01] \mathrm{IC}_{10 \%=}[2.45,3.52]$.

Results of long-term relationships suggest that wheat price is positively and significantly related to those of maize and soybean. On the other hand, the relationship between wheat and rice is negative and statistically significant. As a result, a rise (decrease) in the maize or soybean price leads to a rise (decrease) in the price of wheat while a rise (decrease) in the rice price leads to a fall (rise) in the price of wheat. In addition, the prices of rice, wheat and soybean have significant positive effect at the $1 \%$ level on maize price. In fact, a $1 \%$ rise in the price of rice, wheat and soybean leads respectively to a rise of $0.204 \%, 0.629 \%$ and $0.299 \%$ in maize prices. On the other hand, the results show that the price of rice is long-term negatively and significantly linked to the price of wheat and positively linked to the price of maize and soybean. In addition, a $1 \%$ increase in the price of wheat implies a reduction in the price of rice by $0.250 \%$. On the other hand, a $1 \%$ increase in the maize and soybean price leads respectively to an increase of $0.408 \%$ and $0.434 \%$ in rice price. The price of soybean is positively and significantly linked in the long term to the price of wheat, maize and rice. The results show that a $1 \%$ increase in the price of maize, wheat and rice leads respectively to an increase of $0.361 \%, 0.307 \%$ and $0.262 \%$ in soybean price. The price of oil has a significant long-term effect only on the price of wheat and the price of rice. A one percent increase in the oil price leads to a significant increase of $0.247 \%$ of wheat prices and of $0.348 \%$ of the soybean price.

In the short term, the results show that (table 4) maize and soybean prices positively and instantly affect the price of wheat. Moreover, the maize price is positively sensitive to wheat, rice and soybean price. On the other hand, the results show that the rice price depends negatively on the price of wheat in the short term, positively on maize price, positively and negatively on staggered rice prices, and positively on the soybean price. The price of oil affects the price of rice in the short term. In the case of soybean prices, the results show that the instant prices 
of wheat, maize and rice significantly and positively affect the price of soybean in the short term. However, delayed maize prices have negative effects on soybean prices, while the delayed oil price has a positive and statistically significant effect on soybean prices.

Table 4. Estimated short term coefficient of price dynamic

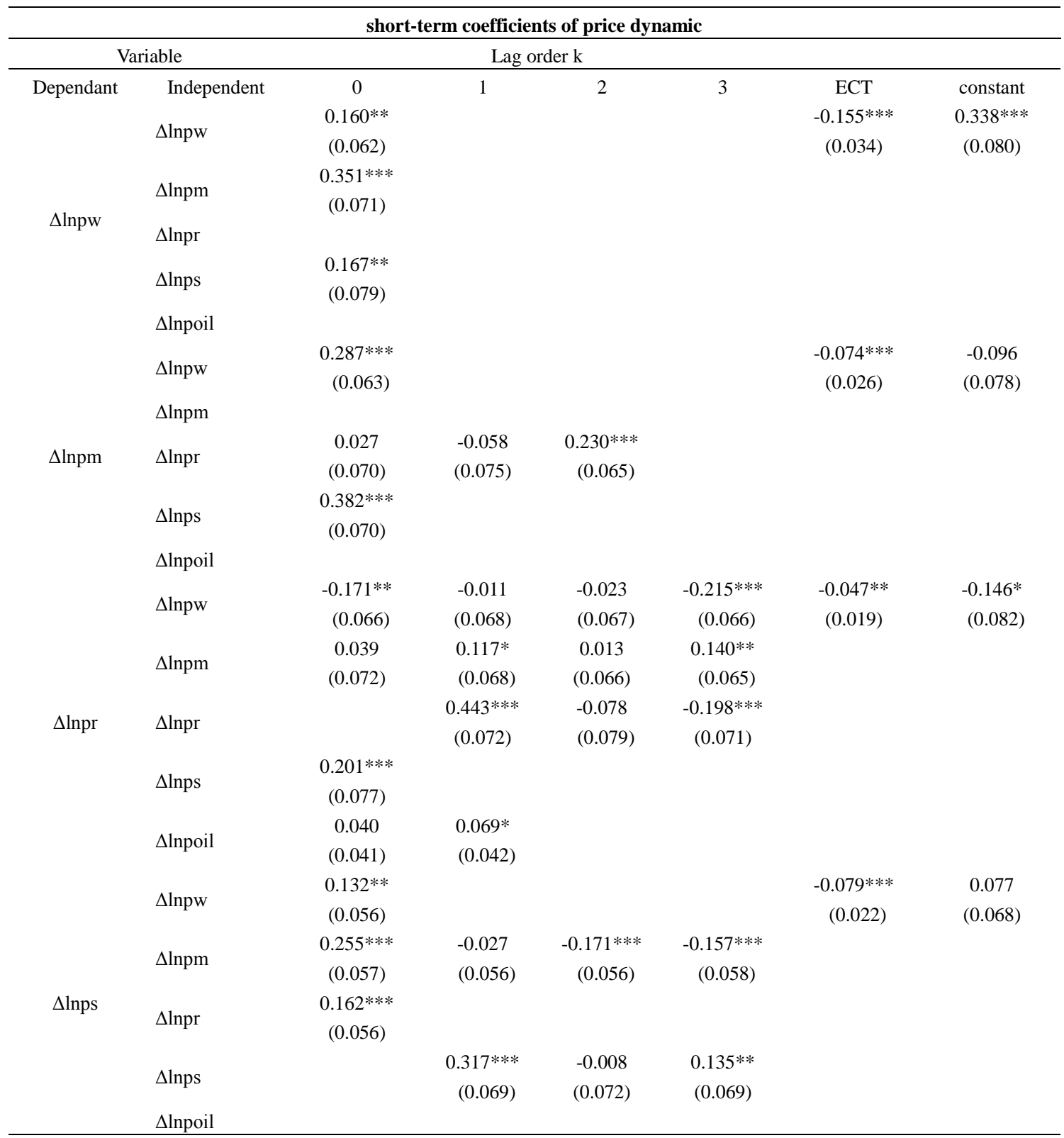

Note. $* * *, * *$ and $*$ denote Significance the $1 \%, 5 \%$, and $10 \%$ level respectively.

The volatility of prices and their interrelationships were analyzed with the multivariate GARCH model. The results of the estimates are summarized in Table 4. 
Table 5. Analysis of the volatility of prices of agri-food commodities

\begin{tabular}{|c|c|c|c|}
\hline Model & Variable & coef. & SE \\
\hline \multirow{3}{*}{ ARCH_dlnpw } & Arch L1 & $0.216^{* *}$ & 0.094 \\
\hline & Garch L1 & $0.622 * * *$ & 0.143 \\
\hline & Cons. & $0.001 * *$ & 0.000 \\
\hline \multirow{3}{*}{ ARCH_dlnpm } & Arch L1 & 0.112 & 0.072 \\
\hline & Garch L1 & $0.450^{*}$ & 0.249 \\
\hline & Cons. & $0.002 * *$ & 0.001 \\
\hline \multirow{3}{*}{ ARCH_dlnpr } & Arch L1 & $0.459 * * *$ & 0.129 \\
\hline & Garch L1 & $0.452 * * *$ & 0.097 \\
\hline & Cons. & $0.001 * * *$ & 0.001 \\
\hline \multirow{3}{*}{ ARCH_dlnpoil } & Arch L1 & $0.239 * * *$ & 0.080 \\
\hline & Garch L1 & $0.669 * * *$ & 0.121 \\
\hline & Cons. & 0.001 & 0.001 \\
\hline \multirow{5}{*}{ Correlation } & $(\Delta \operatorname{lnpw}, \Delta \operatorname{lnpm})$ & $0.515^{* * *}$ & 0.066 \\
\hline & $(\Delta \operatorname{lnpw}, \Delta \operatorname{lnpr})$ & -0.031 & 0.087 \\
\hline & ( $\Delta$ lnpw, $\Delta$ lnpoil) & 0.104 & 0.089 \\
\hline & $(\Delta \operatorname{lnpm}, \Delta \operatorname{lnpr})$ & 0.110 & 0.089 \\
\hline & $(\Delta \operatorname{lnpm}, \Delta \operatorname{lnpoil})$ & 0.148 & 0.095 \\
\hline \multirow{2}{*}{ Adjustment } & Lambda 1 & $0.049^{*}$ & 0.026 \\
\hline & Lambda 2 & 0.750 *** & 0.112 \\
\hline
\end{tabular}

The sum of the lambda 1 and lambda 2 adjustment parameters, significantly less than one, validates the robustness of our model. In addition to the short and long terms relationships between these commodities the price volatilities (rice, soybean corn and wheat) are autoregressive at the 5\% significance level. As a matter of fact, the current volatility of agricultural commodity prices in the world market is significantly related to their volatility in previous periods. However, only wheat and maize price volatilities are significantly $(p-v a l u e<1 \%)$ correlated.

\subsection{Effects of Price Dynamics on the Level of Imports of Rice and Wheat in WAEMU Countries}

The West African countries agriculture rice production represents only $50 \%$ of consumers' needs in the sub-region (Lançon and Benz, 2007). According to these authors, rice imports are the most agro-food imports, representing $20 \%$ of the total value of agricultural imports in the sub-region. Torres and Seters, (2016) highlighted that rice and wheat are in the top three imports agricultural and food products imported in the west Africa region specifically in WAEMU countries. For these reasons, we focused on the impact of the world market characteristics on the rice and wheat imports in WAEMU countries.

The ARDL cointegration test between imports and agri-food prices is carried out and reported in table 6. It should be noted that the stationarity tests were performed on the annual series of imports and prices. All series are stationary after the first difference. In Togo and Mali, the rice and wheat imports are combined with their respective prices. On the other hand, for rice (wheat), there is a long-term relationship in Senegal (Côte d'Ivoire). However, there is not any cointegration or inconclusive long-term relationship in Benin and Burkina Faso. All these long-term relationships (Table 6) are positive and significantly at the 5\% level. This is consistent with macro-level imports or imports per capita (Table 6). The relationship between import and price of these products varies across countries.

These results can be explained by the fact that the demand of foodstuffs derived from these agricultural products is increasing and this demand is insensitive to the rise in their price. Furthermore, commodities aggregate demand may be due to the sharp growth of WAEMU countries population. Similarly, at the micro level, the results show that the demand per capita grows even if product prices increase. There are many socioeconomics facts such as growth of income, exchange rate fluctuation, strong urbanization in these countries, and dynamics of consumption behaviors that could explain this situation. In Senegal, rice and wheat remain the main sources of calorific energy for the population (Thaondyandé \& Yade, 2011). The increase in per capita import can be explained by government subsidies on these products. In other countries, rice and wheat are largely in the consumption patterns of urban households. Rural people consume rice mainly during the holiday season. Nevertheless, rural populations are progressively integrating food derived from rice and wheat into their consumption patterns. In west Africa, Over the past 30 years, rice imports have increased by only $3.5 \mathrm{~kg}$ per 
capita, and have actually decreased when measured per capita of the urban population (Vorley \& Lançon, 2016). It means that rice consumption demand in rural are growing in this region.

Table 6. ARDL Cointegration test and estimation of long-term relationships between imports and prices of agricultural commodities (rice and wheat)

\begin{tabular}{|c|c|c|c|c|c|c|c|c|c|c|}
\hline \multirow[b]{2}{*}{ Country } & \multirow[b]{2}{*}{ Importation } & \multicolumn{3}{|c|}{ Global Import } & \multicolumn{3}{|c|}{ Per Capita Import } & \multicolumn{3}{|c|}{ ARDL Cointegration test } \\
\hline & & lnpr & lnpw & cons. & $\operatorname{lnpr}$ & lnpw & cons. & F-test & Lag & Decision \\
\hline \multirow{2}{*}{ Togo } & Rice & $1.411 * * *$ & - & 1.737 & $0.831^{* *}$ & - & $-10.018 * * *$ & 6.439 & 3 & Cointegrated \\
\hline & Wheat & - & $3.137 * * *$ & $-7.063 * *$ & - & $2.569 * * *$ & $-19.339 * * *$ & 9.038 & 4 & Cointegrated \\
\hline \multirow{2}{*}{ Mali } & Rice & $2.969 * * *$ & - & -6.763 & $2.511^{* * *}$ & - & $-20.150 * * *$ & 11.456 & 2 & Cointegrated \\
\hline & Wheat & - & $4.924 * * *$ & $-15.448 * * *$ & - & $4.374^{* * *}$ & $-28.709 * * *$ & 14.308 & 3 & Cointegrated \\
\hline \multirow{2}{*}{$\begin{array}{c}\text { Burkina } \\
\text { Faso }\end{array}$} & Rice & $2.532 * * *$ & - & -3.837 & $2.026^{* * *}$ & - & $-16.940 * * *$ & 5.565 & 3 & Inconclusive \\
\hline & Wheat & - & $0.805^{* * *}$ & $6.106^{* * *}$ & - & 0.195 & $-6.861^{* * *}$ & 4.304 & 4 & No Cointegrated \\
\hline \multirow{2}{*}{ Benin } & Rice & $2.248 * * *$ & - & -1.910 & $1.674^{* * *}$ & - & $-13.993 * * *$ & 2.875 & 2 & No Cointegrated \\
\hline & Wheat & - & $1.851 * * *$ & 0.154 & - & $1.112^{* *}$ & $-11.528 * * *$ & 5.074 & 4 & Inconclusive \\
\hline \multirow{2}{*}{$\begin{array}{c}\text { Cote } \\
\text { d'Ivoire }\end{array}$} & Rice & $1.325 * * *$ & - & $4.849 * *$ & .525 & - & $-6.811^{* * *}$ & 9.293 & 3 & Cointegrated \\
\hline & Wheat & - & $1.154 * * *$ & $6.392 * * *$ & - & $0.211^{* * *}$ & $-5.160 * * *$ & 0.564 & 4 & No Cointegrated \\
\hline \multirow{2}{*}{ Senegal } & Rice & $0.844 * * *$ & - & $8.025 * * *$ & $0.301 * * *$ & - & $-4.645^{* * *}$ & 2.840 & 3 & No Cointegrated \\
\hline & Wheat & - & $0.984 * * *$ & $7.137 * * *$ & - & $0.316 * * *$ & $-5.313 * * *$ & 6.244 & 3 & Cointegrated \\
\hline
\end{tabular}

Note: $* * * * *$ and $*$ denote Significance the $1 \%, 5 \%$, and $10 \%$ level respectively.

Table 7 presents the results of the estimates of short term relationships between imports and agricultural commodity prices. In general, lags in imports variables for wheat and rice have negative effects on current imports except for Mali. Moreover, for the later, there is not any significant effects. The results also show that rice imports are significantly and negatively sensitive to its price and its delayed values in Togo, in Mali and in Burkina Faso. By contrast, the current price has a positive effect on the rice import while its delayed values have negative effects in Mali, Benin, Côte d'Ivoire and Senegal. In addition, lags in the wheat price have a negative effect on import in all countries.

Annual prices volatilities have negative effects on the rice and wheat import in all countries except for Côte d'Ivoire and Burkina Faso whose wheat price's volatility has a significant positive effect on imports. This suggests that companies are risk averse and play strategies to minimize the effects of price volatility on their economic activities. They acquire stocks at low commodities prices to serve the population during periods of soaring prices on the international market.

Table 1. Estimates of the coefficients of short-term relations between imports and prices of agricultural commodities (rice and wheat)

\begin{tabular}{|c|c|c|c|c|c|c|c|c|}
\hline Country & Dependent & Independent & 0 & 1 & 2 & 3 & ECT & Constant \\
\hline \multirow{12}{*}{ Togo } & \multirow{6}{*}{$\Delta \operatorname{lnRice}$} & & & $-0.226^{*}$ & & & $-0.224 * * *$ & $-3.568 *$ \\
\hline & & $\Delta \ln$ Rice & & $(0.132)$ & & & $(0.079)$ & (1.778) \\
\hline & & & 0.368 & $-1.734 * * *$ & & & & \\
\hline & & $\Delta \operatorname{lnpr}$ & $(0.594)$ & $(0.465)$ & & & & \\
\hline & & & -0.117 & $-0.282 *$ & & & & \\
\hline & & lnsd_pr & $(0.159)$ & $(0.163)$ & & & & \\
\hline & \multirow{7}{*}{$\Delta \ln W h e a t$} & & & $-0.339 * *$ & $-0.234^{*}$ & & $-0.368 * * *$ & 1.254 \\
\hline & & $\Delta \ln W h e a t$ & & $(0.132)$ & $(0.127)$ & & (0.097) & $(2.591)$ \\
\hline & & & -0.001 & 0.371 & $-1.987 * * *$ & & & \\
\hline & & $\Delta \operatorname{lnpw}$ & $(0.829)$ & (0.624) & $(0.683)$ & & & \\
\hline & & & 0.095 & 0.101 & & & & \\
\hline & & lnsd_pw & $(0.184)$ & (0.189) & & & & \\
\hline \multirow{5}{*}{ Mali } & & $\Delta \operatorname{lnRice}$ & & & & & & \\
\hline & \multirow{4}{*}{$\Delta \operatorname{lnRice}$} & & $1.741^{* *}$ & -0.012 & $-1.693 * *$ & $-2.567 * * *$ & $-0.398 * * *$ & -3.237 \\
\hline & & $\Delta \operatorname{lnpr}$ & (0.797) & (0.704) & $(0.666)$ & $(0.649)$ & $(0.101)$ & (3.237) \\
\hline & & & $-0.420^{*}$ & & & & & \\
\hline & & lnsd_pr & $(0.235)$ & & & & & \\
\hline
\end{tabular}




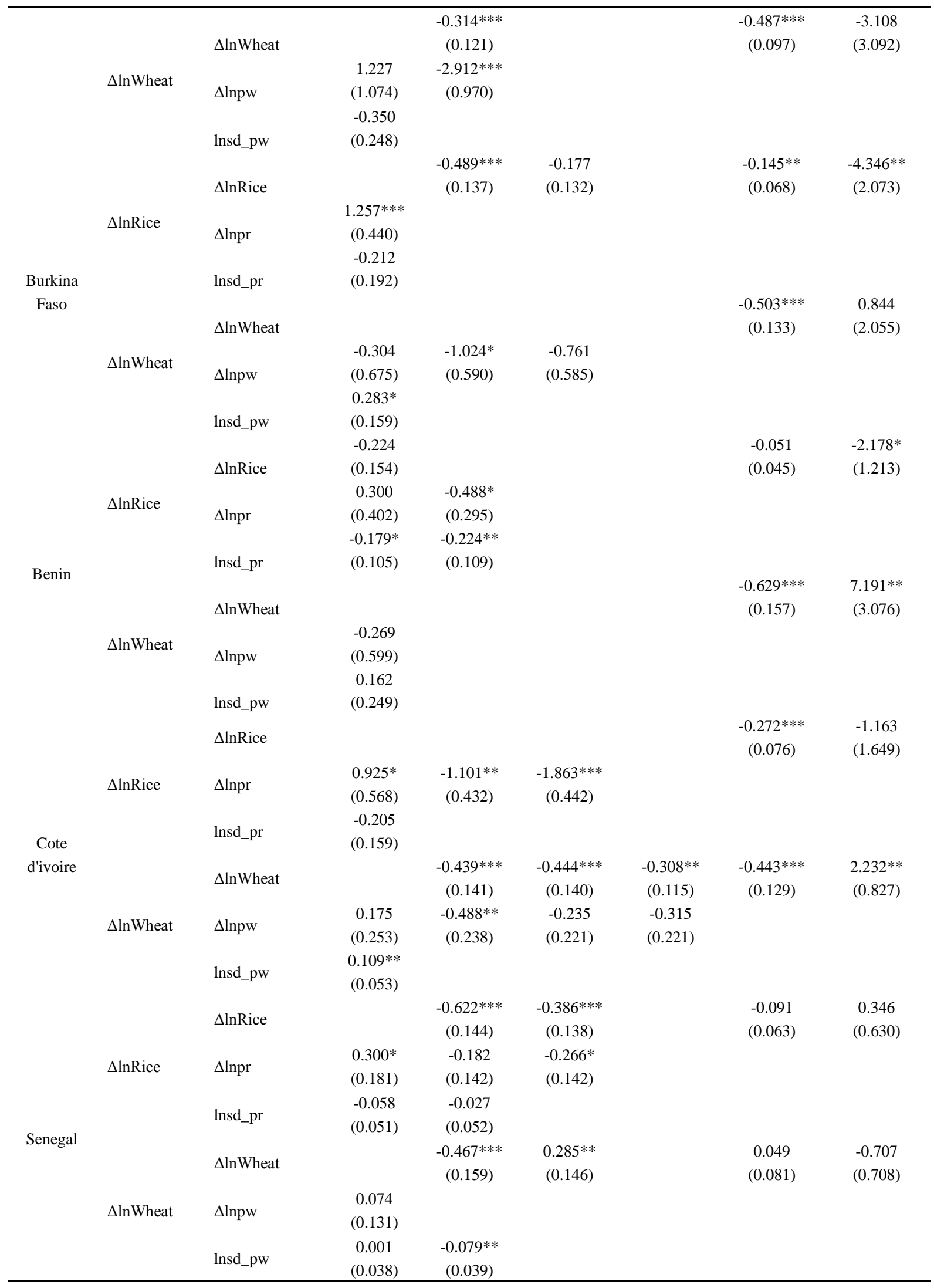

Note. $* * * * *$ and $*$ denote Significance the $1 \%, 5 \%$, and $10 \%$ level respectively. Standard Error is in parentheses (.).

Our findings suggest that the WAEMU countries heavily dependent on imports of these agricultural products and are strongly affected by the volatility of prices, and even by those of products of which they do not import. Price 
Dynamics of agricultural products are significantly dependent; importing countries are threatened by soaring prices. It is therefore important for importing countries with agricultural potential to develop strategies promoting the production of these agricultural products at the local level in order to mitigate subsidy spending and food insecurity, improve availability and accessibility. The following section attempts to analyze the effects of the price dynamics of rice and wheat on their volatility on the level of imports of these products for Togo, Mali, Burkina, Benin, Cote d'Ivoire and Senegal.

\section{Criticisms of Certain Food Security Policies in WAEMU Countries: Case of Togo}

The main objective of this section is to conduct a criticism analysis of food security policy implemented in WAEMU countries and their impact on rural population welfare through the price and livelihoods analysis. WAEMU countries have their food security programs which have common objectives. However, each country adapts their policies to their local contexts. There is a lack of critical analysis on these programs operation and their efficiency. In this study, we focused on the case of Togo and more specifically on the Togo National Food Security Agency.

\subsection{Togo National Food Security Agency (ANSAT in French)}

Most farmers in Togo are smallholders. According to the Agricultural Census Report (MAEP, 2014), 77\% of cultivated plots have less than 0.5 hectares and more than $91 \%$ are less than one hectare. During the 2012 campaign, only $33.50 \%$ of the plots were fertilized (MAEP, 2014). The National Food Security Agency of Togo (ANSAT) is responsible for collecting and purchasing surplus production during harvesting periods in order to build up stocks that are re-injected at affordable prices on the market during welding. This ensures the availability and accessibility of food during hard periods.

\subsection{Budget, Gross Agricultural Domestic Product and Rural Population}

Figure 2 shows the evolution over the period 2002 to 2013 of the share of the national budget allocated to the development of agricultural sector, the share of the rural population and the share of the Agricultural Gross Domestic Product (AGDP) in the total wealth created at National level. The agricultural sector contributes at about $40 \%$ of national GDP and the rural population accounts for more than $60 \%$ of the total population. Agricultural and agro-pastoral activities are the means of subsistence for this rural population. However, the share of the national budget allocated to the development of agriculture highlights that the authorities give less importance to this sector. As a matter of fact, the State devotes about 5\% of its annual budget to the agricultural sector which contributes to $40 \%$ of the wealth created and directly depends on two thirds of the national population. Farmers do not have access to productive resources (fertilizer, improved seeds, credit), road and storage infrastructure are virtually non-existent in rural areas, and the working tools remain rudimentary. Farmers are exposed to enormous post-harvest losses due to the lack of storage and the effects of climate change with the prolongation of rainy seasons and floods.

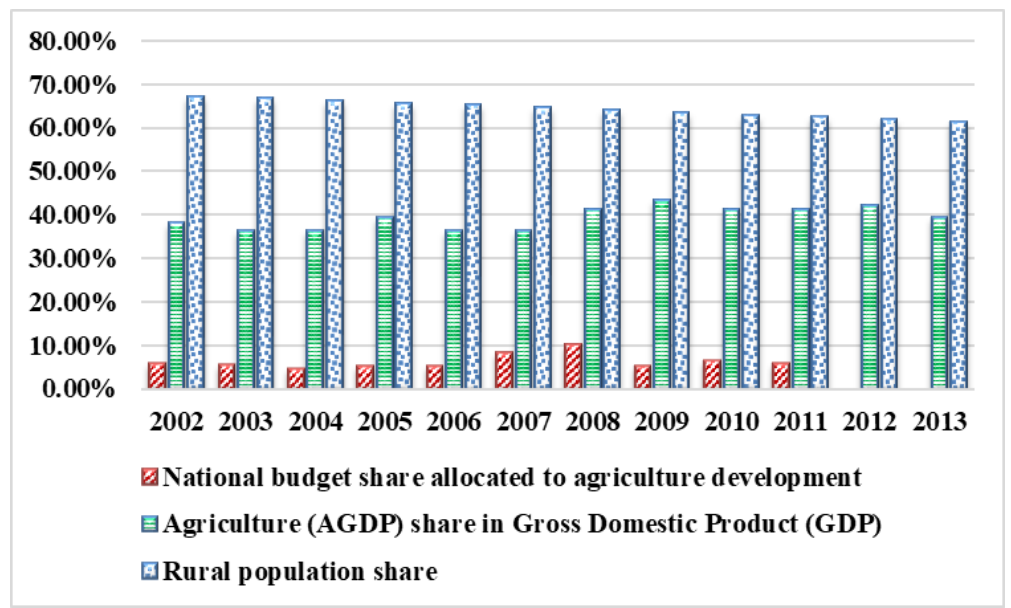

Figure 1. Dynamic of agriculture budget share, rural population share and Agricultural Gross Product share

\subsection{Small-Holder Farmers and ANSAT: Buyers or Sellers and When?}

Since smallholder's farmers do not have storage facilities for all their production, even though these productions 
are insufficient for their annual consumption, they sell a large part of their production to ANSAT and to traders. Moreover, during the harvesting periods, agricultural prices are very low, namely maize's, the main food crop in the country and the main source of calorific energy for the population and the rural one specifically.

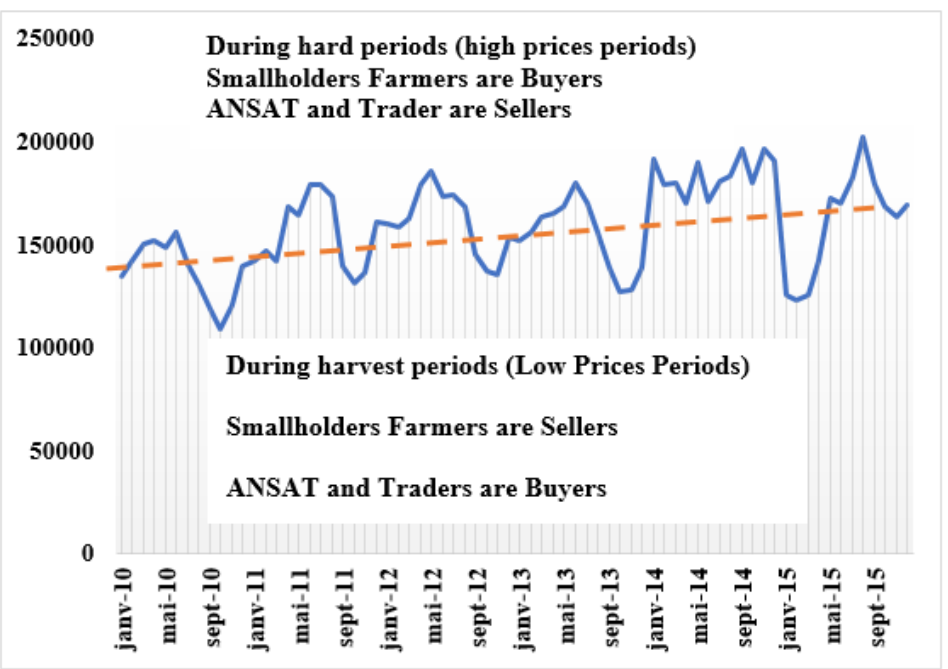

Figure 2. Corn price (in XOF per ton)

Farmers consume the rest of their production over the rest of the season until December. From January to the new rainy season, the majority of rural households are in periods of food shortage due to the fact that they have exhausted their entire stock. Thus, during harvest periods, producers are sellers (low prices period) and ANSAT is the main buyer. On the other hand, during the lean periods (January-June), prices are very high and ANSAT is the seller and the smallholder's farmers are buyers. Figure 3 above shows the dynamic of the domestic corn price in XOF over the period January 2010 to December 2015 (data obtained from the FAO site). This graph also presents the grace periods and the hard periods as well as the changes of status of the economic actors in the market depending on the state of the period.

\subsection{Livelihoods of Smallholder Farmers During Periods of High Corn Price and Implications for Nutrition}

During hard periods, many rural households suffer from hunger, food and nutritional inadequacies. Smallholder households use alternative livelihoods to survive: selling small livestock (goats, sheep) and poultry, hunting and picking fruit and bush products. The sale provides them with low income for the purchase of food. Rising prices of major staple foods deprive many rural households of access to adequate and safe food. Households plan their consumption once a day. Children and pregnant women suffer from nutritional and nutrient deficiencies.

\section{Conclusion}

The objectives of this paper were to (i) analyze short and long-term relationships between prices of rice, wheat, maize and oil; (ii) examine the transmission of shocks between these prices; and (iii) evaluate the impact of shocks and price volatility on their import in each WAEMU countries. Understanding the dynamic of prices and their impact on imports on which the countries depend heavily provides a better framework for agricultural policies to meet food and nutrition security targets. WAEMU countries have high agricultural production potential that remains untapped, yet they remain heavily dependent on imports of agricultural commodities. The sharp rise in prices makes households with low incomes vulnerable to malnutrition. To attempt these objectives, we have conducted autoregressive distributed lag models (ARDL), Granger causality test and multivariate GARCH model on monthly data from January 1999 to December 2016. Annual prices and imports data (1961-2016) were used to assess the impact of price shocks on agricultural commodities imports.

The results show that there is a statistically significant bi-directional causality relationship between maize and soybean prices and between rice and wheat prices. Moreover, rice and wheat prices are significantly sensitive to maize price shock. The price volatility of rice, corn, soybean and wheat is autoregressive. Overall, these price volatilities are positively and significantly connected to each other. We find that in the short term as well as in long term, commodities prices are affecting each other. The change in the price of energy significantly affects the price of rice in the short term. In short, there is strong synergy between changes in the prices of agricultural 
products. This further suggests that a sharp increase in one of these prices may lead to a general surge in food prices and consequently to a food crisis.

In short term, rice imports are significantly and negatively sensitive to its price and its delayed values in Togo, Mali and Burkina Faso. By contrast, current rice price has a positive effect on imports while its delayed values have negative effects in Mali, Benin, Côte d'Ivoire and Senegal. In addition, previous wheat prices have negative effects on imports in all countries. Rice and wheat imports are respectively cointegrated with their prices in the case of Togo and Mali. Wheat imports are cointegrated with their price in Senegal. However, the long-term relationship between rice imports and their price is not statistically significant. The annual price volatility has significant negative effects on rice and wheat imports in all WAEMU countries.

To summarize, these empirical findings suggest that the levels and volatility of agricultural commodities prices in world markets strongly affect the availability and accessibility of food in WAEMU countries that are highly dependent on their imports. Policy makers must adopt appropriate strategies to increase agricultural production and reduce their dependence on imports.

\section{References}

Alam, M. J., \& Jha, R. (2016). Asymmetric Threshold Vertical Price Transmission in Wheat and Flour Markets in Dhaka (Bangladesh): Seemingly Unrelated Regression Analysis. The Australian National University, Australia South Asia Research Centre.

Alemu, Z. G., \& Ogundeji, A. A. (2010). Price transmission in the South African food market. Agrekon, 49, 433-445. https://doi.org/10.1080/03031853.2010.526691

Ankamah-Yeboah, I., \& Bronnmann, J. (2017). Asymmetries in import-retail cost pass-through: Analysis of the seafood value chain in Germany. Aquaculture Economics \& Management, 21, 71-87. https://doi.org/10.1080/13657305.2016.1262478

Baek, J., \& Koo, W. W. (2009). Assessing the exchange rate sensitivity of US bilateral agricultural trade. Canadian Journal of Agricultural Economics/Revue canadienne d'agroeconomie, 57, 187-203. https://doi.org/10.1111/j.1744-7976.2009.01147.x

Composante, S. (2011). PRESAO. Résumé 8.

CNUCED. (2008). Répondre à la crise alimentaire globale. Nations Unies, New York et Genève, 2008.

CRAAQ. (2008). La production d'éthanol à partir de grains de maïs et de céréales. no EVC 029.

Enders, W., \& Siklos, P.L., (2001). Cointegration and threshold adjustment. Journal of Business \& Economic Statistics, 19, 166-176. https://doi.org/10.1198/073500101316970395

Engle, R. F., \& Granger, C. W. (1987). Co-integration and error correction: representation, estimation, and testing. Econometrica:Journal of the Econometric Society, 251-276. https://doi.org/10.2307/1913236

Gross, C. (2017). Assessing the Common Dynamics of Commodity Futures Prices.

Hahn, R. W. (2008). Ethanol: Law, Economics, and Politics. SSRN Scholarly Paper ID 1082079. Rochester, NY: Social Science Research Network. https://doi.org/10.2139/ssrn.1082079

Jebabli, I., Arouri, M., \& Teulon, F. (2014). On the effects of world stock market and oil price shocks on food prices: An empirical investigation based on TVP-VAR models with stochastic volatility. Energy Economics, 45, 66-98. https://doi.org/10.1016/j.eneco.2014.06.008

Johansen, S. (1995a). Identifying restrictions of linear equations with applications to simultaneous equations and cointegration. Journal of Econometrics, 69, 111-132. https://doi.org/10.1016/0304-4076(94)01664-L

Johansen, S. (1995b). Likelihood-based inference in cointegrated vector autoregressive models. Oxford University Press on Demand. https://doi.org/10.1093/0198774508.001.0001

Lançon, F., \& Benz, H. D. (2007). October. Rice imports in West Africa: Trade regimes and food policy formulation. In Poster prepared for presentation at the 106 th seminar of the EAAE, 25-27 October 2007, Montpellier.

Maetz, M. (2012). La vérité sur les crises alimentaires: La responsabilité accablante de politiques économiques désastreuses. Retrieved from http://www.lafaimexpliquee.org

Mensi, W., Hammoudeh, S., Nguyen, D. K., \& Yoon, S. M. (2014). Dynamic spillovers among major energy and cereal commodity prices. Energy Economics, 43, 225-243. https://doi.org/10.1016/j.eneco.2014.03.004 
MAEP. (2014). Principales Caractéristiques de l'Agriculture Togolaise.

Ning, Z., \& Sun, C. (2014). Vertical price transmission in timber and lumber markets. Journal of Forest Economics, 20, 17-32. https://doi.org/10.1016/j.jfe.2013.07.002

O’Brien, D. (2011). World corn supply-demand trends: an “At Risk" position for MY 2011/12. Grain Outlook Archives.

Perron, P. (1989). The great crash, the oil price shock, and the unit root hypothesis. Econometrica: Journal of the Econometric Society, 1361-1401. https://doi.org/10.2307/1913712

Pesaran, H., \& Shin, Y. (1999). An Autoregressive Distributed Lag Modelling Approach to Cointegration chapter 11. In Econometrics and Economic Theory in the 20th Century, The Ragnar Frisch Centennial Symposium. https://doi.org/10.1017/CCOL521633230.011

Pesaran, M. H., Shin, Y., \& Smith, R. J. (2001). Bounds testing approaches to the analysis of level relationships. Journal of Applied Econometrics, 16, 289-326. https://doi.org/10.1002/jae.616

Pesaran, M. H., Shin, Y., \& Smith, R. P. (1999). Pooled mean group estimation of dynamic heterogeneous panels. Journal of the American Statistical Association, 94, 621-634. https://doi.org/10.1080/01621459.1999.10474156

Rezitis, A. N. (2015). The relationship between agricultural commodity prices, crude oil prices and US dollar exchange rates: A panel VAR approach and causality analysis. International Review of Applied Economics, 29, 403-434. https://doi.org/10.1080/02692171.2014.1001325

Sadorsky, P. (2014). Modeling volatility and correlations between emerging market stock prices and the prices of copper, oil and wheat. Energy Economics, 43, 72-81. https://doi.org/10.1016/j.eneco.2014.02.014

Sissine, F. (2007). Energy Independence and Security Act of 2007: A summary of major provisions. Library of Congress Washington DC Congressional Research Service.

Stuber. (2001). Le caractère évolutif de l'incidence des chocs énergétiques sur l'activité économique et sur l'inflation. Revue de la Banque du Canada

Sun, C. (2011). Price dynamics in the import wooden bed market of the United States. Forest Policy and Economics, 13, 479-487. https://doi.org/10.1016/j.forpol.2011.05.009

Surathkal, P., Chung, C., \& Han, S. (2014). Asymmetric adjustments in vertical price transmission in the US beef sector: Testing for differences among product cuts and quality grade. In Selected Paper of Agricultural and Applied Economics Association Annual Meeting, Minneapolis, MN, July.

Taondyande, M., Sylla, M., \& Oumaro, S. (n. d.). Dynamique de la consommation alimentaire dans la sous-région Ouest-Africaine: principales tendances.

Taondyandé, M., \& Yade, M. (2012). Etude sur la Consommation Alimentaire en Afrique de l'Ouest. AGWA Background Paper. Ibadan, Nigeria: ReSAKSS West Africa.

Torres, C., \& Van Seters, J. (2016). Overview of trade and barriers to trade in West Africa: Insights in political economy dynamics, with particular focus on agricultural and food trade. Discussion Paper 195. Maastricht: ECDPM.

UNCTAD. (2008). Réponse à la crise alimentaire globale: Les politiques essentielles pour le commerce, l'investissement, et les produits de base afin d'assurer la sécurité alimentaire durable et d'atténuer la pauvreté. Nations Unies

Vorley, B., \& Lançon, F. (2016). Food consumption, urbanisation and rural transformation. IIED Working Paper.

Wang, Y., Wu, C., \& Yang, L. (2014). Oil price shocks and agricultural commodity prices. Energy Economics, 44, 22-35. https://doi.org/10.1016/j.eneco.2014.03.016

Yacobucci, B. D. (2011). Biofuels incentives: A summary of federal programs. DIANE Publishing. 


\section{Appendix A}

Dynamics of agricultural commodities prices and import by WAEMU countries

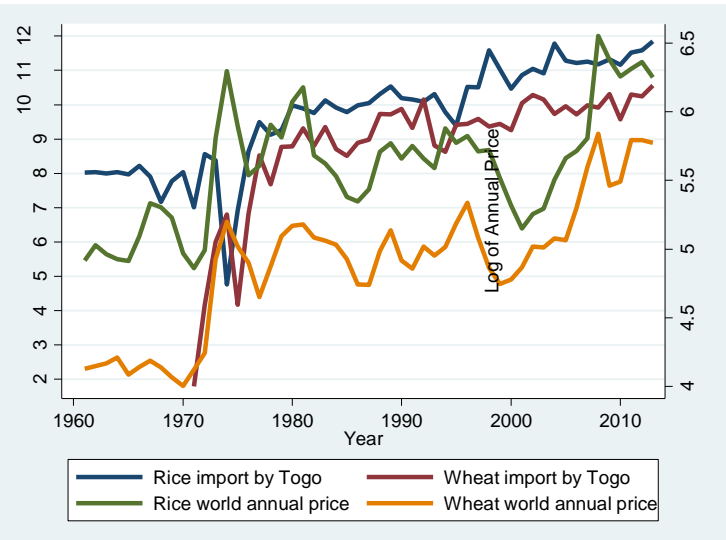

Panel Togo

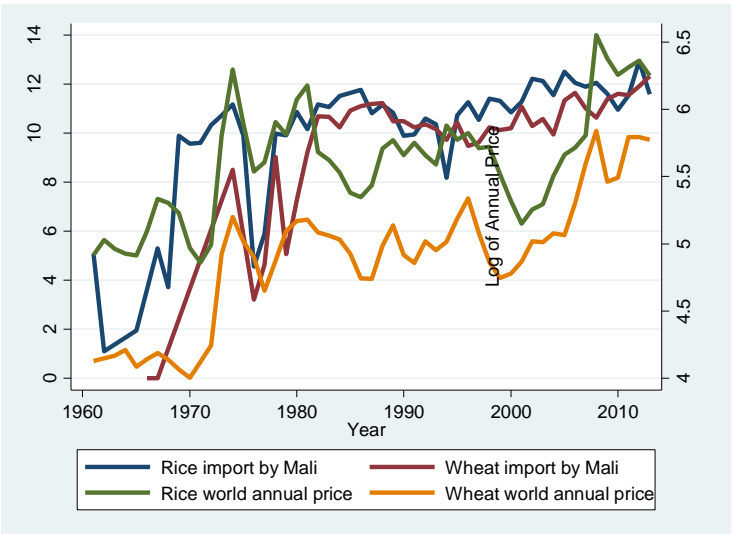

Panel Mali

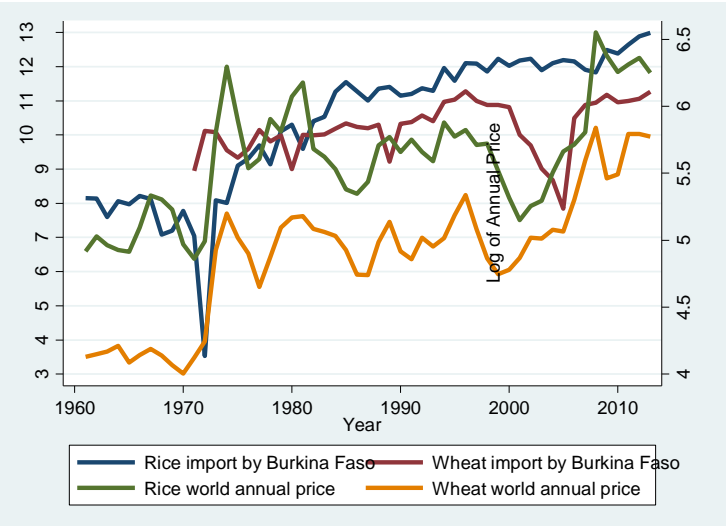

Panel Burkina Faso

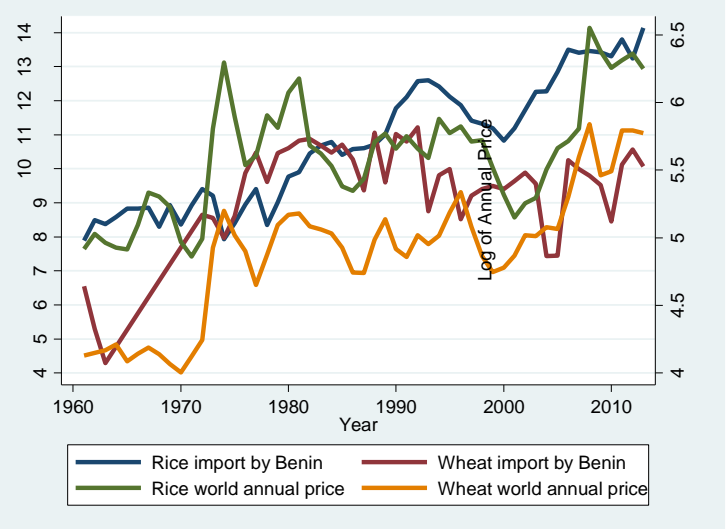

Panel Benin

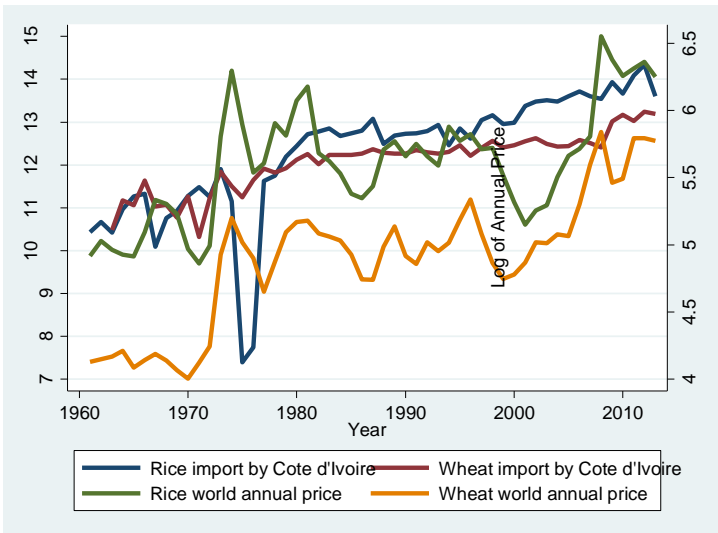

Panel Côte d'Ivoire

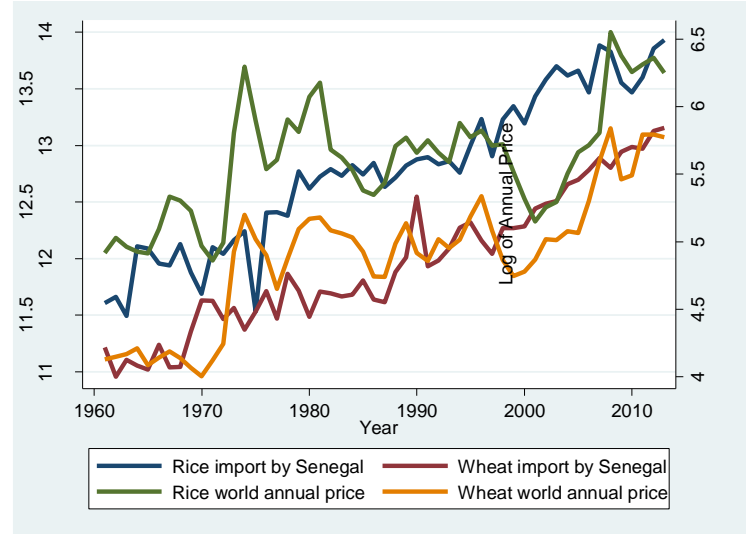

Panel Senegal

Figure 4. Evolution of logged import levels of rice and wheat according to annual world prices of rice and wheat

\section{Copyrights}

Copyright for this article is retained by the author(s), with first publication rights granted to the journal.

This is an open-access article distributed under the terms and conditions of the Creative Commons Attribution license (http://creativecommons.org/licenses/by/4.0/). 